\title{
Adaptability of Kitchen Furniture for Elderly People in Terms of Safety
}

\section{Sigurnosna prilagođenost kuhinjskog namještaja starijim osobama}

\author{
Preliminary paper • Prethodno priopćenje \\ Received-prispjelo: 7. 9. 2011. \\ Accepted-prihvaćeno: 16. 5. 2012. \\ UDK: $630 * 836 ; 674.23$ \\ doi:10.5552/drind.2012.1128
}

\begin{abstract}
The number of senior citizens is rapidly increasing, which consequently signifies an increase in the number of people having sight, hearing or memory difficulties, people with hampered mobility, and people who find it increasingly difficult to process information. Elderly persons experience a greater degree of risk whilst performing daily tasks in their kitchens. Moreover, they are more susceptible to infection and illnesses, necessitating greater care to achieve hygienic conditions within their kitchens. The goal of our research was to determine whether people are generally content with the functionality of their kitchens and whether the degree of dissatisfaction increases with the age of the users. The study aims to pinpoint any major problems facing elderly people whilst working in their kitchens and to establish criteria for kitchen furniture design that could be tailored to senior users' interests, with the focus on safety. This research was carried out via individual surveys at the respondents' homes. 204 respondents participated in the research. The results show that most users do not realize that, with more appropriate kitchen equipment, they could perform daily tasks faster, safer, and with less effort. Common shortcomings include insufficient lighting (32\%), inappropriate sequential composition of work surfaces (56\%), ease of hygiene maintenance (68\%), inappropriately - shaped furniture (72\%), and tasks that become troublesome because of declining memory (75\%). We believe that it is necessary to design kitchen equipment specifically adjusted for the needs of the elderly.
\end{abstract}

Key words: kitchen, elderly, senior, equipment, design, safety, ergonomics

SAŽETAK • Udjel starijih osoba u stanovništvu u enormnom je porastu, slijedom čega se povećava broj ljudi koji imaju slabiji vid, sluh, memoriju, fizičke probleme i probleme s percipiranjem informacija. Stariji su zbog toga osjetljiviji na ozljede, koje mogu nastati pri obavljanju svakodnevnih poslova u kuhinji. Osim toga, za njihovu je sigurnost važno voditi brigu o higijenskim standardima jer su osjetljiviji na infekcije i bolesti. Cilj ovog istraživanja bio je utvrditi jesu li ljudi zadovoljni funkcionalnošću njihove kuhinje i osjećaju li se sigurno te raste li nezadovoljstvo kuhinjom sa starošću korisnika. Željeli smo identificirati probleme s kojima se pri radu u kuhinji suočavaju stariji ljudi i utvrditi kriterije za izradu kuhinjskog namještaja prilagođenoga starijim ljudima u smislu sigurnosti. Istraživanje je provedeno putem osobnih intervjua u domu ispitanika. U istraživanju su sudjelovala 204

\footnotetext{
Author is associated professor at the Academy of Design, Ljubljana, Slovenia. ${ }^{2}$ Author is assistant professor employed at the National Museum of Contemporary History, Ljubljana, Slovenia. ${ }^{3}$ Author is associated professor at the Academy of Design, Ljubljana, Slovenia. ${ }^{4}$ Author is associated professor University of Ljubljana, Biotechnical Faculty, Department of Wood Science and Technology, Ljubljana, Slovenia. ${ }^{5}$ Author is assistant professor employed at Vox medii d.o.o., Ljubljana, Slovenia

${ }^{1}$ Autorica je izvanredna profesorica Akademije dizajna, Ljubljana, Slovenija. ${ }^{2}$ Autorica je docentica zaposlena u Nacionalnome muzeju suvremene umjetnosti, Ljubljana, Slovenija. ${ }^{3}$ Autorica je izvanredna profesorica Akademije dizajna, Ljubljana, Slovenija. ${ }^{4}$ Autor je izvanredni professor Biotehničkog fakulteta Sveučilišta u Ljubljani, Ljubljana, Slovenija. ${ }^{5}$ Autor je docent zaposlen u tvrtki Vox medii d.o.o., Ljubljana, Slovenija.
} 
ispitanika. Rezultati istraživanja pokazuju kako ljudi ne znaju da bi uz prikladniju opremu brže, lakše i sigurnije mogli obavljati svakodnevne zadatke. Starije osobe u kuhinji prije svega imaju probleme sodržavanjem higijene$68 \%$, s neodgovarajućim rasporedom kuhinjskih centara - 56\%, s neadekvatnom rasvjetom - 32\%, s nepropisno dizajniranim namještajem - $72 \%$, s problemima slabijeg pamćenja - $75 \%$. Vjerujemo da je potrebno projektirati kuhinjski namještaj prilagođen specifičnim zahtjevima starijih osoba.

Ključne riječi: kuhinja, starije osobe, oprema, dizajn, sigurnost, ergonomija

\section{INTRODUCTION}

\section{UVOD}

Owing to an increasingly higher standard of living as well as improvements in health care, the proportion of senior citizens in the general population is rapidly increasing. Statistical prognosis indicates that, by $2030,36 \%$ of people will be over the age of 60 (Hilderbrand, 2002). Information from the Statistical Office of the Republic of Slovenia states that, in 2010, the percentage of Slovenian citizens over 60 years of age was $21.97 \%$, out of which $58.21 \%$ were female (Statistic Office RS, 2010). There had also been an increase in the number of citizens with sight issues, hampered movement capabilities, and degrees of memory loss. In Slovenia dementia is encountered in over 25,000 people and the number is ever-increasing. Among citizens older than 85 years, almost half suffer from dementia and every tenth person suffering from it is younger than 50. Over the next 20 years, the number of people suffering from dementia is likely to double.

In 2004 researchers from the University of Sheffield, School of Architecture carried out the research into the influence of architecture on the quality of life. They were chiefly interested in how appropriate the common living quarters were, for the research focused on the suitability of the design of retirement homes. That research was carried out in 38 retirement homes, and the results showed that there are both positive and negative aspects implicit in the design of the buildings, which is all the more important because senior citizens spend a great deal of time indoors. Among other findings, they determined that closely following hygienic standards are crucial due to the increased susceptibility of the elderly to disease and infections and that particular care needs to be taken in the design of spaces where food is prepared and/or consumed (Torrington et al, 2004). Colombo and his colleagues (1998) analyzed 26 flats and identified the most commonly occurring problems facing the elderly. $33 \%$ of the flats were identified as having kitchen-security issues, and $25 \%$ as having inadequate lighting. Pinto et al, noted that one of the most common causes of injury in a home environment for the elderly is the changing of light bulbs if, in doing so, the elderly person has to stand on a chair or ladder (Pinto et al, 2000).

Research has also shown that due to social and financial reasons, a large percentage of senior citizens, especially those with movement impediments, tend to remain indoors for longer periods of time. This challenges the designers of living quarters regarding additional requirements, in particular how to facilitate movement for people with disabilities and how to improve their quality of life in general. The majority of flats are designed for young, fit, and active people. Many senior inhabitants do not possess these attributes, meaning that even performing the simplest home tasks is more taxing for them. Furthermore, inappropriately designed housing space can lead to health issues such as backache or injuries from accidents. Research has shown that adapting living space to the needs of the elderly can reduce the risk of injury by $30 \%-50 \%$. The age of the furniture and equipment in their homes also plays an important part in determining functionality. According to research, $60 \%$ of the senior population lives in homes that have not been renovated or refurnished for over 20 years, contributing to lower safety and comfort levels, (Home Remodeling..., 2006). Comfort is crucial for the elderly, as they spend most of their time at home. Over $14 \%$ of English elder citizens live in unfit conditions, in homes that are in dire need of renovation and adaptation (Boyo, 2001). Yet only $10 \%$ of them decide to modify their existing furniture and equipment to reflect their special needs (Gilderbloom et al, 1996; Katsura et al, 1989). They often refrain from renovating due to financial concerns, lessening mobility and fear of the upheaval of renovation work. Furthermore, the research also shows that the elderly also suffer from inappropriate room dimensions including rooms that are too big for them (West and Emmitt, 2004).

According to data issued by the Statistical Office of the Republic of Slovenia, citizens over the age of 60 accounted for only $11.84 \%$ of the changes made to residences in 2008. Other data suggests that senior citizens rarely decide to change their home environments, which contributes to a lowering of comfort levels and environments ill-suited for accommodating residents with special needs, and to lower safety levels. Most people are also reluctant to live in a retirement home, and only do so when they are entirely incapable of living by themselves. In Great Britain, only $4 \%$ of citizens between the age of 65 and 69 live in a retirement home, $7 \%$ between the age of 70 and 74, $10 \%$ between 75 and $79,13 \%$ between 80 and 85 and $19 \%$ of people older than 85 (National Statistics GB, 2003). In Slovenia, $7 \%$ of the population resides in a retirement home. Of course, senior citizens who require aid at home have different design needs than those who are capable of living by themselves (Schwarz, 1997). A good solution is to design modern residential units with architectural and furniture elements that are ergonomically adjusted for elderly or handicapped users, from the standpoint of both safety and functionality. Boyo (2001) claims that $10 \%$ of elderly users suffer from difficulties regarding kitchen mobility.The essence of design is to understand the specific needs and wishes of the end-users 
.... Hrovatin, Širok, Jevšnik, Oblak, Berginc: Adaptability of Kitchen Furniture for Elderly ...

Table 1 Respondent age

Tablica 1. Starost ispitanika

\begin{tabular}{|l|c|c|c|c|c|c|c|c|c|}
\hline & $\begin{array}{c}55-59 \\
\text { years } \\
\text { godina }\end{array}$ & $\begin{array}{c}60-64 \\
\text { years } \\
\text { godine }\end{array}$ & $\begin{array}{c}65-69 \\
\text { years } \\
\text { godina }\end{array}$ & $\begin{array}{c}70-74 \\
\text { years } \\
\text { godine }\end{array}$ & $\begin{array}{c}75-79 \\
\text { years } \\
\text { godina }\end{array}$ & $\begin{array}{c}80-84 \\
\text { years } \\
\text { godine }\end{array}$ & $\begin{array}{c}85-89 \\
\text { years } \\
\text { godina }\end{array}$ & $\begin{array}{c}90+ \\
\text { years } \\
\text { godina }\end{array}$ & $\begin{array}{c}\text { Total } \\
\text { Ukupno }\end{array}$ \\
\hline Women / Žene & 42 & 27 & 25 & 25 & 16 & 11 & 7 & 153 \\
\hline Men / Muškarci & 12 & 9 & 7 & 9 & 8 & 4 & 1 & 1 & 51 \\
\hline $\begin{array}{l}\text { Women and Men together } \\
\text { Žene i muškarci, ukupno }\end{array}$ & 54 & 36 & 32 & 34 & 24 & 15 & 8 & 1 & 204 \\
\hline
\end{tabular}

Table 2 Age of respondents' kitchens

Tablica 2. Starost kuhinja ispitanika

\begin{tabular}{|l|c|c|c|c|c|c|}
\hline & \multicolumn{5}{|c|}{ Kitchen age / Starost kuhinje } \\
\hline & $\begin{array}{c}\text { Less than 5 years / } \\
\text { Manje od 5 godina }\end{array}$ & $\begin{array}{c}5-9 \\
\text { years } \\
\text { godina }\end{array}$ & $\begin{array}{c}10-14 \\
\text { years } \\
\text { godina }\end{array}$ & $\begin{array}{c}15-19 \\
\text { years } \\
\text { godina }\end{array}$ & $\begin{array}{c}20-29 \\
\text { years } \\
\text { godina }\end{array}$ & $\begin{array}{c}\text { More than 30 } \\
\text { years / Više } \\
\text { od 30 godina }\end{array}$ \\
\hline $\begin{array}{l}\text { Number of respondents } \\
\text { Broj ispitanika }\end{array}$ & 38 & 27 & 33 & 34 & 59 & 13 \\
\hline $\begin{array}{l}\text { Share in percent, \% } \\
\text { Udio u postocima }\end{array}$ & 19 & 13 & 16 & 17 & 29 & 6 \\
\hline
\end{tabular}

(Margolin, 1997). The goal of the current research was to discover whether people are satisfied with the functionalities of their kitchens, whether they feel safe or not whilst using them and whether or not the degree of dissatisfaction increased with the respondents' age. Our desire was to establish the main issues that seniors face when using a kitchen and to establish criteria for improving the design of kitchen furniture tailored for the senior citizens, in order to give them greater independence, safety, and quality of life.

\section{MATERIAL AND METHODS}

\section{MATERIALI I METODE}

The research was carried out via individual surveys. The survey only included people over the age of 55. 210 questionnaires were filled in, of which 204 were valid. The respondents were aged between 55 and 91 (Table 1). Most respondents, $76 \%$, were aged between 55 and 74 . The survey pool consisted of $75 \%$ women and $25 \%$ men. The questionnaire consists of 54 questions and is divided into 4 parts. In the first part, questions focus on general data of respondents' flats and number of people who live there. The second part of the questionnaire examines tasks in the kitchen. The third part collects functionality data concerning the kitchen and the last part examines consumer behavior. This paper has been focused on questions concerning security and functionality issues.

The majority of respondents (57\%) live in a single apartment home, whilst the remainder lives in houses with multiple apartments. When compared to the overall data for Slovenia, where $64 \%$ of households exist in a single-apartment house, this represents a satisfactory sample (Statistical Office of the Republic of Slovenia, Census 2002).

The survey was carried out in the respondents' homes. Most questions were closed-ended, using a yes/ no dichotomy, but some were multiple choice questions. Very few questions were open-ended, only the ones that were expected to provide the most varied array of answers. In regard to information about the proper arrangements of work surfaces and implements, the interviewer carrying out the survey answered the questions after receiving detailed instructions on how to assess the arrangement.

\section{RESULTS}

\section{REZULTATI}

We were interested in the age of the respondents' kitchen equipment. Table 2 shows that $35 \%$ of respondents have a kitchen older than 20 years, whilst $52 \%$ have a kitchen older than 15 years.

The respondents were asked whether they were satisfied with their kitchen, and the results are shown in Table 3 . It is noteworthy that $72 \%$ of them were satisfied with their kitchen arrangements, despite the fact that the majority of kitchens were inadequate in their functional or ergonomic designs.

Table 3 Satisfaction with the degree of kitchen functionality Tablica 3. Prikaz zadovoljstva opremom kuhinje

\begin{tabular}{|l|c|c|}
\hline & $\begin{array}{l}\text { Yes } \\
D a\end{array}$ & $\begin{array}{l}\text { No } \\
\text { Ne }\end{array}$ \\
\hline $\begin{array}{l}\text { Number of answers } \\
\text { Broj odgovora }\end{array}$ & 147 & 57 \\
\hline $\begin{array}{l}\text { Percentage ratio, \% } \\
\text { Postotni udje, \% }\end{array}$ & 72 & 28 \\
\hline
\end{tabular}

Figure 1 shows the results of the answers to the question as to what bothers the respondents the most in their kitchen. Only those who expressed dissatisfaction with their kitchens answered this question. They had the possibility to choose several negative factors. The respondents who answered that they were dissatisfied with the functionality of their furniture and lighting were asked to elaborate as to what in particular bothered them. They cited: inadequate lighting over the kitchen work surfaces and inside the cupboards, inap- 


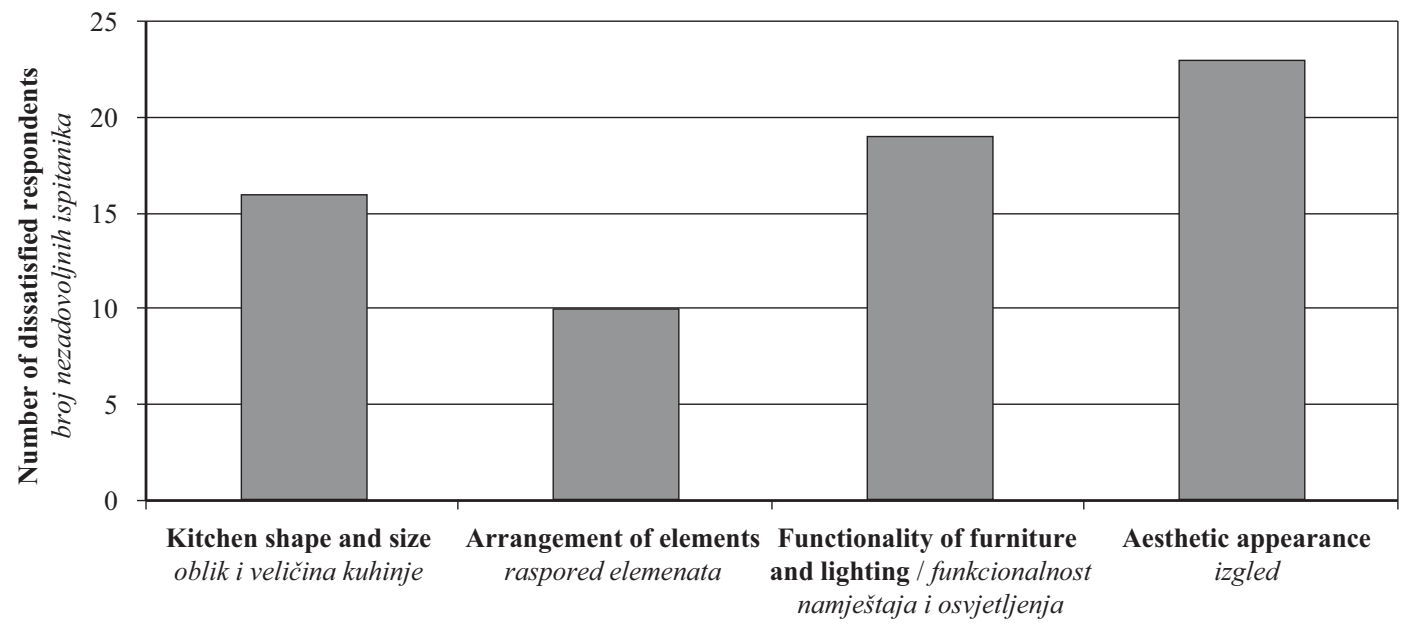

Figure 1 Graphical representation of respondents' dissatisfaction with kitchen elements

Slika 1. Grafički prikaz nezadovoljstva ispitanika kuhinjama

propriate height of shelves, oven, refrigerator, troublesome cleaning set-up (e.g. contact between wall and work surface, contact between work surface and kitchen appliances), inadequate handle design (e.g. too small, slippery, fall off, in the way), hard-to-reach places in the corners or shelves under the cupboards.

Figure 2 shows a succession of elements that we deem appropriate. We took into consideration the darkly colored parts. An appropriate width for a work surface was deemed to be between 60 and $150 \mathrm{~cm}$. Over half $(56 \%)$ of the subjects had an inappropriate arrangement of the three main work areas (Table 4).

Table 4 Respondents' satisfaction with arrangement of the three main work areas and an adequate width of the main work surface

Tablica 4. Udjel ispitanika koji imaju primjeran redoslijed radnih zona i primjernu širinu radne površine

\begin{tabular}{|l|c|c|}
\hline & Yes / Da & No / Ne \\
\hline $\begin{array}{l}\text { Adequate arrangement of main areas } \\
\text { and adequate width of main work } \\
\text { surface / Primjeren redoslijed radnih } \\
\text { zona i primjerena širina radne } \\
\text { površine }\end{array}$ & 89 & 115 \\
\hline Percentage (\%) / Postotak & 44 & 56 \\
\hline
\end{tabular}

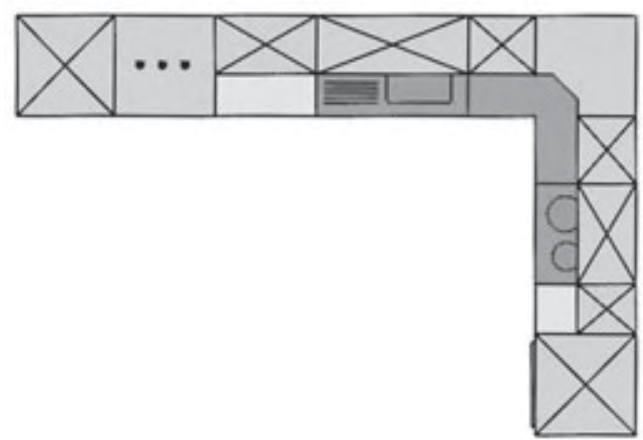

a) L - shaped kitchen / kuhinja u obliku slova L

Figure 2 Adequate arrangement of three main work areas Slika 2. Primjeren redoslijed radnih zona u kuhinji
We were interested in the degree to which senior users were prepared to use modern technology and computers. Out of 15 persons who stated they used a computer, 14 were younger than 65 . A somewhat higher percentage $(21 \%)$ would be comfortable with using kitchen robots (Table 5).

When posed the question as to what caused them the most problems when cleaning their surfaces, the respondents indicated that most problems were caused by the transition between the stove and the work surface and the edges of the sink and stove.

Respondents were asked what caused them the most problems when cleaning their cupboards. Most reported problems are caused by the profiled surfaces of doors and decorative openings. Some $44 \%$ of respondents chose this answer. A little fewer respondents (40 $\%$ ) reported a problem cleaning the handles. Only $16 \%$ have problems related to materials ill-suited for cleaning. Respondents were also given the option of listing other problematic elements, which included wall-mounted and corner cupboards, because the shelves are hard to reach, and the top sides of the tall and wall-mounted cupboards are too high to reach and clean easily. They find it hard to clean under raised cupboards, as well as cleaning the bottoms of the cupboards themselves.

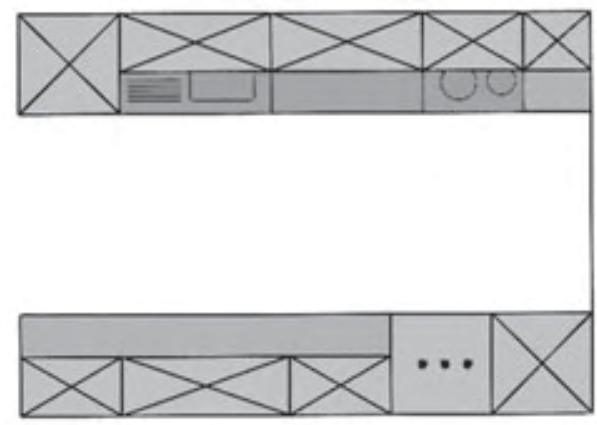

b) two - way kitchen / dvostruko smještena kuhinja 
.... Hrovatin, Širok, Jevšnik, Oblak, Berginc: Adaptability of Kitchen Furniture for Elderly ...

Table 5 Percentage of respondents who use a computer and those who would be willing to use a kitchen robot

Tablica 5. Razmjer ispitanika koji upotrebljavaju kompjutor i onih koji bi bili spremni upotrebljavati kuhinjske robote

\begin{tabular}{|l|l|c|c|}
\hline & & Yes / Da & No / Ne \\
\hline $\begin{array}{l}\text { Do you use a computer at home? } \\
\text { Upotrebljavate li kompjutor kod kuće? }\end{array}$ & Number of answers / Broj odgovora & 27 & 177 \\
\hline & Percentage, \% / Postotak, \% & 13 & 87 \\
\hline $\begin{array}{l}\text { Would you be prepared to use kitchen robots? } \\
\text { Jeste li spremni upotrebljavati kuhinjske robote? }\end{array}$ & Number of answers / Broj odgovora & 43 & 161 \\
\hline & Percentage, \% / Postotak, \% & 21 & 79 \\
\hline
\end{tabular}

Senior citizens often tend to have bad eyesight. We asked the respondents whether or not their kitchen light sources were positioned correctly and whether or not they were placed in such a way to cast the user's shadow directly on to the area where work was performed. Table 6 shows that about a third (32\%) of the respondents have what they perceived to be inadequately lit work surfaces.

Table 6 Appropriateness of lighting source in regards to casting shadows

Tablica 6. Primjernost položaja rasvjete s obzirom na sjene

\begin{tabular}{|l|c|c|}
\hline $\begin{array}{l}\text { Are your light sources positioned so that } \\
\text { the user's shadow is not cast onto work } \\
\text { surfaces? / Jesu li svjetla postavljena tako } \\
\text { da sjena korisnikova tjela pada na radnu } \\
\text { površinu? }\end{array}$ & No & Ne \\
\hline Number of respondents / Broj odgovora & 66 & 138 \\
\hline $\begin{array}{l}\text { Percentage, \% } \\
\text { Postotak, \% }\end{array}$ & 32 & 68 \\
\hline
\end{tabular}

We were interested in finding out how many respondents had light sources in their kitchen that required them to climb up on something to change bulbs. The results show that all but one respondent have such inappropriate light sources.

Many senior citizens suffer from bad memory. We asked the respondents whether or not they faced problems connected with bad memory whilst performing kitchen tasks, and if yes, in what specific ways. About a quarter $(24 \%)$ of respondents did not report having a bad memory, whilst the others claimed to suffer from this problem in the kitchen. Those that answered affirmatively were asked specifically how bad memory made their kitchen tasks harder to perform. Respondents were given the option of choosing multiple answers. $35 \%$ of them had forgotten to buy all the ingredients required to cook a meal, $29 \%$ had forgotten that they have food cooking, resulting in charred or burnt meals, $26 \%$ had forgotten what ingredients they had already put in a meal (spices), whilst $10 \%$ had forgotten to close the fridge door, turn off the stove or had left water running.

Senior citizens are less agile, having more difficulty moving around a room, which means they suffer from a greater risk of injury. We asked the respondents whether or not they bumped into open cabinet cupboard or sharp surface and table edges whilst performing kitchen tasks, such as preparing food or emptying the dishwasher. The results show that $72 \%$ have had problems with bumping into doors or corners.
We were also interested in whether or not respondents had problems with slippery kitchen floors. The results show that most $(60 \%)$ do not have a slippery floor covering whilst others face this problem occasionally, particularly when the floor is wet. We noted the types of floor coverings the respondents used and concluded from this that most of those who claimed to have problems with slippery floors used either linoleum or ceramic tiles; two had a stone floor.

\section{DISCUSSION}

\section{DISKUSIJA}

It had originally been surmised that most senior users would be dissatisfied with the functionality of their kitchens. However, the majority of respondents (72\%) were indeed satisfied with their kitchen, despite the fact that $56 \%$ of them were found to have unsuitably arranged work surfaces, trouble with maintaining a hygienic environment, that over a third had unsuitable lighting arrangements, and that over half of respondents $(52 \%)$ had kitchens older than 15 years. The results show that users are typically unaware that they could perform their daily tasks faster, with less effort, and a greater degree of safety.

Those that were dissatisfied with their kitchens again gave surprising results, since most were uncomfortable with aesthetics rather than functionality. It had been anticipated that senior users would be more dissatisfied by the functionality of their kitchen, as they tend to suffer from restricted agility, sight and/or memory issues. It appears that they become used to their kitchen and have limited desire for change. They typically attribute the problems they face when using their kitchen to their advancing age, but are unaware of the fact that their problems could be lessened if the space were adapted to their needs. Therefore we are of the opinion that householders over the age of 55 should already be looking into kitchens that are adapted for use by senior citizens so as to become accustomed to it whilst they are still active, and get used to new environments with greater ease.

Our research shows that $56 \%$ of respondents have an inappropriate work surface arrangement. A more functional and safer kitchen working environment is gained by appropriately arranging its elements. Particularly important is the arrangement of the kitchen sink, the main work surfaces and stove, this being the part of the kitchen where most of the cooking process takes place. An appropriate arrangement is one which allows the user to remain in one spot whilst preparing food (slicing, cutting, peeling, washing), whilst and at 
the same time monitoring the food that is already being cooked (stirring, adding). Additionally, the adjacent position of the sink and stove would mean that the user needs to travel a shorter distance if he or she needs to pour away boiling water.

It is assumed that in the future, so-called, intelligent" technology will make an important contribution to kitchen usage and will ease the workloads of users by a sizeable amount. The fact that very few of the respondents use a computer was to be expected and corresponds to the conclusion that most (79\%) would not want a robot in their kitchen to help out. Many senior users have trouble adapting to new technology, and most of them have no wish for it at all. At present, users over 65 years old are not potential customers for robotically-aided kitchens. In 10 years however, when 65 will be of an age at which people have become familiar with computers in their active years, a robotically-aided kitchen will be much more attractive to elderly users. It will be necessary however, as Casals et al. (2000) determined, to make the commands and controls simple, easy-to-use and user-friendly.

„Smart" kitchen appliances are a step in this direction. The research shows that $29 \%$ of users who have memory issues tend to leave stoves on, which can easily create a fire hazard. From the point of view of safety, this means intelligent stoves with the option of setting cooking times and automatic shut-off systems when operating with an empty container or without one at all. Intelligent refrigerators are also a welcome addition, for example ones capable of ordering groceries on the internet via a display on the refrigerator door. The refrigerator monitors one's food inside via labels and barcodes, whilst also noting the purchase dates of products, and then warning about the expiry date. The use is not complicated, and as senior users tend to have problems with mobility, this addition could be of great help to them. Due to the senior users' difficulties in keeping up with new technologies it would be necessary to carefully select the appliances that are easy to use and have clear, intuitive interfaces.

The possibility of maintaining hygiene in a kitchen is of great importance for senior users, who are more susceptible to infection. The research findings indicate that they report trouble cleaning, in particular handles, profiled surfaces and unsuitable transitions between work-surfaces, walls and appliances. We therefore recommend smooth doors made of materials that are easy to clean. A good solution is a handle-free cupboard which opens by pressure alone. The surface should be entirely of one piece, with proper joint between work-surface and wall, with a sink and stove mounted to avoid gaps or thresholds that make cleaning harder.

Cupboards placed under work-surfaces with a base reaching fully to the floor facilitate cleaning, since senior users find it difficult to bend and sweep underneath cupboards. Similarly, the top sides of tall and wallmounted cupboards are problematic areas, and therefore we advocate avoiding wall-mounted cupboards, preferably building them inside the walls themselves, if necessary.

Kitchen safety also relates to good lighting. An adequate light level for work surfaces is a necessity. By the contrast to the Slovenian data, research in Italy, Colombo et al. (1998) shows that $25 \%$ of kitchens have inadequate lighting conditions. According to our data, the amount of inadequately lit kitchens among senior users in Slovenia is even greater - 32 \%. Additionally, nearly all users have light sources that require climbing on to chairs or ladders to change light bulbs, which is why we recommend wall lamps and lamps with LED, which last for many years.

Senior users in US tend to have sight and agility problems, which compounds the problem of slippery floors in a kitchen. Every year, $30 \%$ of users over the age of 65 experience a fall in their kitchen, a danger that can lead to serious injury or even death (Stevens, 2005). Additionally, such injuries account for a sizeable expenditure by the health services. The costs involved in reducing the risk of falls and providing for a safer environment would be comparably lower (Valente et al, 1998). To lower the risk of injury, walkways between rooms should not have thresholds or changes in elevation. Additionally, the floor covering should be non-slippery. Our research shows that as many as $72 \%$ of users bump into open doors and various sharp edges during kitchen work. When designing a kitchen for the elderly, it should be taken into consideration that bumping into rounded edges is less painful and safer, which is why we advocate such a realization of edges, whilst sliding cabinet doors are preferable to the hinged variety, and entirely remove the problem of bumping into open doors.

\section{CONCLUSIONS 5. ZAKLJUČAK}

Most users who renovate their kitchen at an older age count on it being used for the rest of their lives. Yet the results of this research show that most people are unaware of the importance of ergonomic adaptations to the specific needs that old age brings. Manufacturers should design kitchen furniture systems that would allow for implementation adapted for special needs and should inform buyers more about the significance of an adequately furnished kitchen, heeding the needs of advanced age.

Kitchen design for the elderly should take into consideration the following:

- A carefully planned arrangement (correct succession) of elements and appliances, which allows for the straightforward, safe, and swift performance of tasks with the minimum required motion;

- To prevent falling, passages between rooms should be without changes in elevation and thresholds, whilst the floor should be non-slippery;

- Local lighting of all work surfaces should be such that no obstructing shadows are cast (e.g. own body, etc); 
- Lighting where the user need not trouble themselves with changing light-bulbs (e.g. wall-mounted light sources, LED lighting);

- Furniture and counters with rounded edges;

- Materials and furniture design should allow for easy cleaning (e.g. smooth surfaces, rounded transitions, very few open shelves);

- For ease of cleaning, cabinets without handles are preferred, and if handles are included, they should be designed for users with lessened agility in mind, and should be easy to clean;

- It is advisable to use cupboards with bases that reach all the way to the floor and arrangements that prevent the gathering of dust and dirt on the top parts of hanging and tall cupboards;

- Wall-mounted cupboards with sliding doors;

- Stoves and ovens with automatic shut-off systems or with a signal light and sound, drawing attention to a hot element left unattended, as well as an option to set cooking times;

- Appliances must allow for easy and streamlined use and must include straightforward and intuitive commands. Control buttons must be in plain sight and adapted for users with deteriorating eyesight. Of particular importance is a clear indication as to whether the appliance is ON or OFF.

Considering that designers, when planning objects for home use, tend to have in mind the 19 to 65 age-group, we expected modern kitchen furniture to neglect the needs of the elderly. The research has identified the needs of the elderly and is, as such, of help to designers and architects when designing kitchen environments for the elderly. Therefore, our findings relate to the Dorst \& Cross (2001), who for successful design recommend the interaction between goals and ideas. Due to the extensive nature of the subject, this research was chiefly concerned with the question of safety, whilst future research would elaborate on the subject of dimensional adequacy. The research will be carried out by a computer simulation model. The technology of 3D modeling is already being integrated into the design for other products Mijović at al. (2001) and Smardzewski (2009). The results of this research will be used to plan a kitchen that will allow for effective usage and provide safety and comfort to senior users. It will be developed in collaboration with one of the established kitchen manufacturers. The main objective of each company would be an efficient and successful operation. There is a general economic principle: to achieve the maximum result with the minimum of means (Oblak et al, 2008). The effective use of design can contribute positively to business performance (Bruce et al, 1999). During the congress „Wellness-Inseln zu Hause schaffen" in Stuttgart, it has been pointed out that the „Best-Ager" (45+) and „Silver-Ager“ (65+) demographic groups are strong buyers with high demands, making them groups that are rapidly gaining in significance (JN., 2003). In the future, we would broaden the research to include other parts of residential unit, thus providing criteria for the design of homes for the elderly.

\section{REFERENCES}

\section{LITERATURA}

1. Boyo, S. 2001: When a house is not a home. Older People and their housing, London: AGE - Age Concern England: 65.

2. Bruce, M.; Cooper, R.; Vazquez, D. 1999: Effective design management for small businesses, Design Studies. 20: 297$315 \mathrm{http} / / / \mathrm{dx}$.doi.org/10.1016/S0142-694X(98)00022-2.

3. Colombo, M.; Vitali, S.; Molla, G.; Gioia, P.; Milani, M. 1998: The home environment modification program in the care of demented elderly, Arch. Gerontol.Geriatr. suppl. 6: 83-90

http://dx.doi.org/10.1016/S0167-4943(98)80015-0.

4. Casals, A.; Cufi, X.; Freixenet, J.; Marti, J.; Munoz, X. 2000: Friendly interface for objects selection in a robotized kitchen, ICRA 2000:IEEE International Conference on Robotics and Automation, San Francisco, 24-28. 4. 2000, Institute of Electrical and Electronics Engineers Inc.

5. Dorst, K.; Cross, N. 2001: Creativity in the design process: co-evolution of problem-solution, Design Studies 22: 425$437 \mathrm{http} / / / \mathrm{dx}$.doi.org/10.1016/S0142-694X(01)00009-6.

6. Gilderbloom, J.I.; Affairs, U.; Markham, J.P. 1996: Housing Modification Needs of the Disabled Elderly: What Really Matters?, Environment and Behavior. 28(4): 512$535 \mathrm{http}: / / \mathrm{dx}$.doi.org/10.1177/0013916596284005.

7. Hilderbrand, H. 2002: Für Ältere und Behinderte, BM. 57 (3): 36 .

8. JN. 2003: Wohnst du noch oder lebst du schon, dds Das magazin für möbel und ausbau. 84 (6): 80-81.

9. Margolin, V. 1997: Getting to know the user, Design Studies. 18: 277-236 http://dx.doi.org/10.1016/S0142-694X(97)00001-X.

10. Oblak, L.; Jelačić, D.; Motik, D.; Grladinović, T. 2008: A model for stock management in a wood-industry company, Wood research. 53(1): 105-116.

11. Mijović, B.; Ujević, D.; Baksa, S. 2001: Visualization of Anthropometric Measures of Workers in Computer 3D Modeling of Work Place, Collegium Antropol. 25 (1): 639-650

12. Pinto, M.R.; De Medici, S. 2000: Ergonomics, gerontechnology, and design for the home-environment, Applied Ergonomics. 31 (3): 317-322 http://dx.doi.org/10.1016/S0003-6870(99)00058-7.

13. Schwarz, B. 1997: Nursing home design: a misguided architectural model, Journal of Architectural Planning and Research. 14(4): 343-359.

14. Smardzewski, J. 2009: Antropotechnical aspects of furniture design, Drvna Industrija. 60 (1) 15-21.

15. Stevens, J. A. 2005: Falls Among Older Adults - Risk Factors and Prevention Strategies, Journal of Safety Research. 36(4): 409-411 http://dx.doi.org/10.1016/j.jsr.2005.08.001.

16. Torrington, J.; Barnes, S.; Kevin, M.; Kevin, M.; Tregenza, P. 2004: The influence of Building Design on the Quality of Life of Older People, Architectural Science Review. 47(2): 193-197.

17. Valente, J.; Dignam, T.; Marchman, K.; Mary, C. 1998: Description of a Model Rural, Older Adult Injury Prevention Program for the Home, Housing and Society. 25, (1-2): 53-66.

18. West, B.N.; Emmitt, S. 2004: Functional design? An analysis of new speculative house plans in the UK. Design Studies. 25: 275-299 http://dx.doi.org/10.1016/j.destud.2003.10.002.

19. ***2003: National Statistics GB. 2003 People living in sheltered accommodation by age and household type General Household Survey, table 7 (online). http://www. 
ageconcern.co.uk/AgeConcern; Facts, figures \& research, housing (18.8 2006)

20. ***13.05.2010: Population by age groups and sex, statistical regions, Slovenia, annually. 2010, Statistical Office of the Republic of Slovenia (online) http://www.stat.si/ pxweb/Dialog/varval.asp?ma $=0520308$ E \& ti $=$ Population + by+age+groups + and + sex $\% 2 \mathrm{C}+$ statistical+regions $\% 2 \mathrm{C}$ +Slovenia\%2C+annually\&path=../Database/Demographics/05_population/02_05007_numb_ struct/01_05203_age_sex/\&lang=1

21. ***(12.07.2010) 2008: Net migration and total increase of population by statistical regions (indicators), Slovenia, annually., Statistical Office of the Republic of Slovenia (online)

22. ***http://www.stat.si/pxweb/Dialog/varval.asp?ma $=051$ $5602 \mathrm{E} \& \mathrm{ti}=\mathrm{Net}+$ migration + and + total + increase + of + popu lation + by + statistical+regions $+\% 28$ indicators $\% 29 \% 2 \mathrm{C}+$ Slovenia\%2C+annually\&path=../Database/Demographics/05_population/04_05156_migrations/00_05156_ indicators/\&lang=1 (19.07.2009).

23. ${ }^{* * * 2005}$ : Home Remodeling - Why Is Home Modification And Repair Important? (online) http://www.aoa.gov/
eldfam/Housing/Home_Remodeling/Home_Remodeling.asp;(17.8.2006)

24. ***2002: Population Census results. 2002, Households in dwellings by tenure status, type of building, number of rooms, useful floor space, utility spaces, installations and type of settlement, Slovenia, Statistical Office of the Republic of Slovenia (online)

25. ***http://www.stat.si/popis2002/si/rezultati/rezultati_ red.asp?ter=SLO\&st=44 (19.07.2009).

\section{Corresponding address:}

Assoc. Prof. JASNA HROVATIN, Ph.D.

Academy of Design

Vojkova 63

1000 Ljubljana, SLOVENIJA

e-mail: jasna.hrovatin@vsd.si 